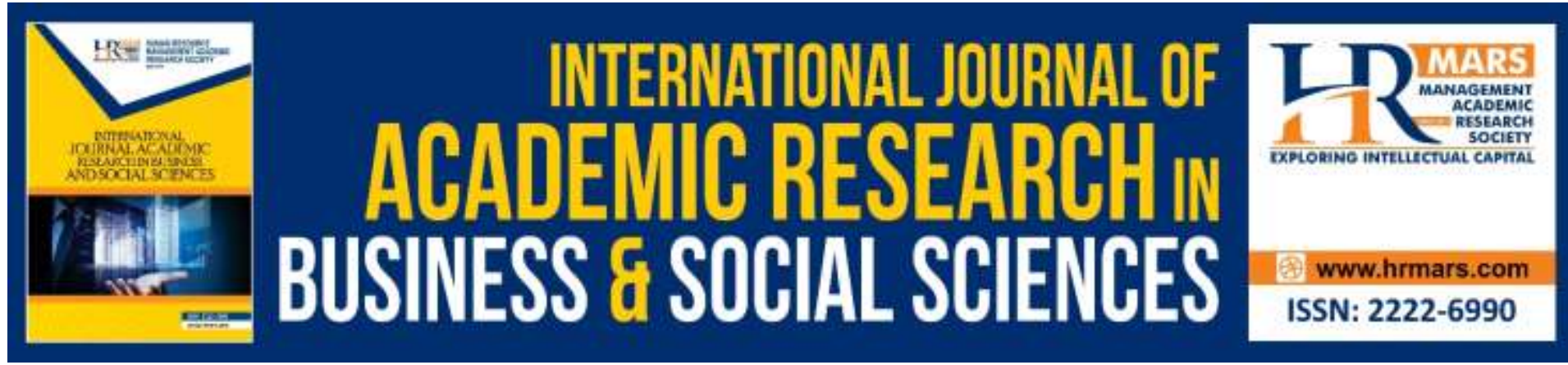

\title{
The Implementation of Flipped Classroom Instructional to Enhance Academic Achievement among form Four Chemistry Students
}

Mohd Ariffuddin Abdul Aziz, Othman Talib, Tajularipin Sulaiman, Nurzatulshima Kamarudin

To Link this Article: http://dx.doi.org/10.6007/IJARBSS/v9-i7/6195

DOI: $10.6007 /$ IJARBSS/v9-i7/6195

Received: 13 May 2019, Revised: 07 June 2019, Accepted: 24 June 2019

Published Online: 29 July 2019

In-Text Citation: (Aziz, Talib, Sulaiman, \& Kamarudin, 2019)

To Cite this Article: Aziz, M. A. A., Talib, O., Sulaiman, T., \& Kamarudin, N. (2019). The Implementation of Flipped Classroom Instructional to Enhance Academic Achievement among Form Four Chemistry Students. International Journal of Academic Research in Business and Social Sciences, 9(7), 967-980.

Copyright: (C) 2019 The Author(s)

Published by Human Resource Management Academic Research Society (www.hrmars.com)

This article is published under the Creative Commons Attribution (CC BY 4.0) license. Anyone may reproduce, distribute, translate and create derivative works of this article (for both commercial and non-commercial purposes), subject to full attribution to the original publication and authors. The full terms of this license may be seen

at: http://creativecommons.org/licences/by/4.0/legalcode

\section{Vol. 9, No. 7, 2019, Pg. 967 - 980}

Full Terms \& Conditions of access and use can be found at http://hrmars.com/index.php/pages/detail/publication-ethics 


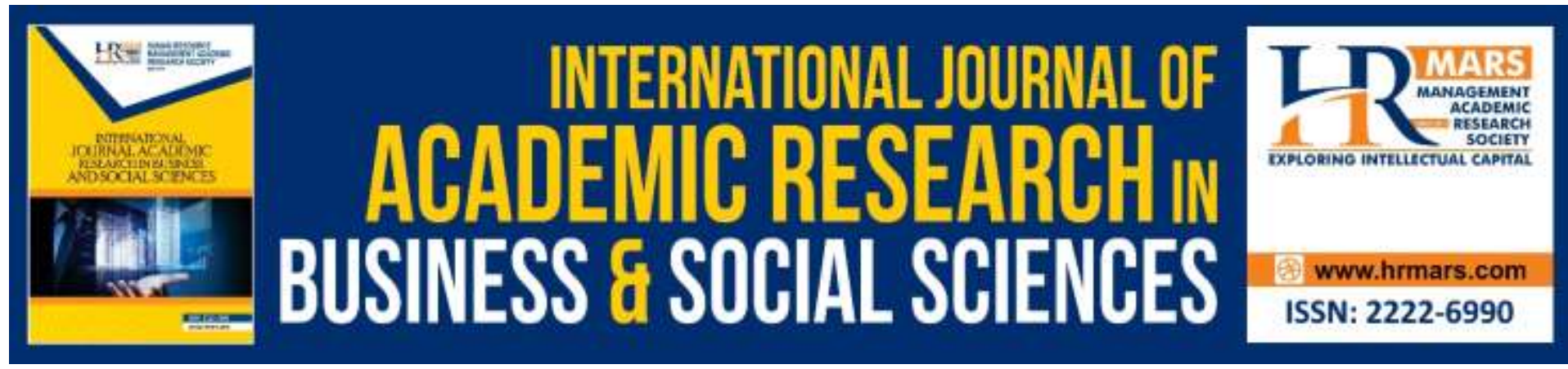

\title{
The Implementation of Flipped Classroom Instructional to Enhance Academic Achievement among Form Four Chemistry Students
}

\author{
Mohd Ariffuddin Abdul Aziz, Othman Talib, Tajularipin \\ Sulaiman, Nurzatulshima Kamarudin \\ Faculty of Educational Studies, University Putra Malaysia \\ Email:mohd.ariffuddin84@gmail.com, otalib@upm.edu.my, tajulas@upm.edu.my, \\ nzshima@upm.edu.my
}

\begin{abstract}
This action research aimed to improve the instructional process through the flipped classroom teaching strategies in order to enhance academic achievement and interest for acid and base topic among the form four chemistry students. The location for this study is located at one of the secondary school in the Hulu Langat District, Selangor. The respondents in this study consists of 32 chemistry students with 17 boys and 15 girls. The research model chosen in this action research is Kurt Lewin's Model (1948). There were two types of instruments used in this study namely as achievement test which involve in the pre-test and the post-test and a survey to measure level of interest among the respondents towards the flipped classroom teaching strategies. The data was analyzed in descriptive and inferential statistics (paired sample t-Test) to determine the value of mean, standard of deviation and the differences of mean's score between the pre-test and post-test. Findings in this study showed that there was an improvement in the post-test with value of mean $66.56(S D=3.88)$ compared to the pre-test with value of mean $51.72(S D=4.11)$. There was a significant differences of mean's score $(t=-23.914, d f=31, p<0.05)$ between pre-test and post-test in this study. The level of interest among the students towards the flipped classroom strategies showed medium high score (Mean= 3.73). These findings showed that flipped classroom teaching strategies could enhance the academic achievement as well as student's interest among the form four chemistry students. The implementation of flipped classroom strategies with the combination of ICT is one of the techniques that can be used to scale up quality of learning across Malaysia using the ICT as stated in the Malaysia Educational Blueprint (2013-2025) at the seven shift. Keywords: Flipped Classroom, Academic Achievement, and Student is Interest and form four Chemistry Students.
\end{abstract}

\section{Introduction}

Over the past two decades, the implementation of information communication and technology (ICT) in education had changed the teaching and learning style in Malaysia. The 
instructional process nowadays was beyond the four wall of classroom through the development of technologies. According to Malaysia Educational Blueprint 2013-2025 in 7th shift, the ministry of education will leverage ICT to scale up quality learning across Malaysia by providing internet technology to schools all over in Malaysia (Ministry of Education, 2012). Consequently, students can learn everywhere, anytime by using the virtual learning environment (VLE) with the existence of internet coverage. Bergmann and Sams (2012) had pointed out that the teaching and learning process while using the internet technology may leverage the learning process in the classroom to ensure that teachers may interact students for a longer time rather than giving lecture. Thus, google has provided Google Classroom application to all of Google's user with the addition of a small size storage. Teachers and students may install this application in their smartphone to make the instructional process become more interesting and effective by giving the teaching materials such as videos, notes and exercises earlier before the class has started.

The teachers may spend more time interacting with the students if they can provide the teaching materials to all of the students earlier. Teachers usually create the video, note or any teaching material so that the students can view and prepare for the lesson topic before coming to class. This new teaching strategy known as "flipped classroom" may improve student's academic achievements and develop a positive attitude towards learning when the learning process occurred outside the classroom through using the technology while the exercises were discussed in the classroom with some interesting learning activities. According to Felder and Strayer (2012) flipped classroom model of instruction is one of the student centered learning strategies that was practiced years ago based on the constructivism theory in which students develop new ideas by using their prior learning experiences.

Student centered learning is key to improving or enhancing academic achievement among the learners by fostering them with active learning and solving their individual learning problem during the instructional process (Kamarainen et al., 2013). Hence, the implementation of flipped classroom learning strategies in the instructional are considered as an example of active learning by engaging students as well as creating meaningful interactions between the teacher and students to produce an effective learning activities. According to Teo and Yeo (2014), the flipped classroom teaching model can promote an active learning process among the students when every student is involved during the discussion between the peer to peer as well as students to teacher.

Chemistry is one of the elective science subject for form four students in Malaysia. In this subject, students are required to think analytically to solve problems in chemistry. One of the topics in chemistry is acid and base which challenge the students to think analytically to solve the reaction between acid and base. In this topic students will be exposed to calculation in order to determine the molarity of acid and base, the products produced through the reaction between acid and base, and to determine whether the acid and base is strong or weak. However, regarding the previous test for this topic, the researcher realized that most of the students are still under the average of passing marks. The researcher came out with an idea to test a teaching strategy called a flipped classroom to enhance the academic achievement and interest of the students focusing on the topic of acids and bases. A study done by Kasim (2003), his study has stated that students with a negative attitude in learning of science subject, for example those who were not interested in science might fail in the subject. Teacher's work load nowadays had increased every year, this situation makes the teachers stressed and difficult to focus in their lesson in the classroom. Malik (2000), had 
pointed out that teacher's work load may cause the teacher to be under pressure and sometimes make it difficult for them to prepare their lesson earlier due to clerical task, handling programs organized by the school and got the special position. The researcher implemented flipped classroom strategies to enhance the effectiveness of teaching and the learning process. In this action research, there are two research objectives as follow:

1) To determine the achievement of students in acid and base topic before and after the teaching and learning using the flipped classroom strategy.

2) To determine the level of interest among the students when implementing flipped classroom strategy in teaching and learning for acid and base topic.

\section{Literature Review}

In order to implement $21^{\text {st }}$ century learning at school, teachers are required to adopt the uses of information technology and communication (ICT) in their pedagogical method and realized how it can helps the students to understand the lesson easier as well as make the learning process become more interactive. Students nowadays are exposed to ICT technologies such as smartphones and computers, by adopting this technology it is easier for the teachers to provide multiple educational resources to them. Students may access the internet in order to obtain the teaching resources from the teachers through online learning materials such as Youtube, online learning and Screencast.com. These technologies may enhance the sharing of educational resources among the teachers and students. The flipped classroom models involve with sharing educational resources from the outside of the classroom to ensure the learning interaction in the class becomes more effective.

According to Tully (2014), instructional process which involves the interactions between teacher and students through the tools of technology is considered a model of flipped classroom. Moreover, the flipped classroom learning style and strategies may create changes in the fundamental of educational context. The concept of flipped classroom is considered a learning process which occurred the traditional learning at home and in the classroom period (Bergmann and Sams, 2012). In addition, the gist of the lesson provided by the teacher through the video will be presented to the students outside the classroom so that the teaching and learning in the classroom will become more interactive due to the preparation of the students before attending to the class.

According to Alzwekh (2014), flipped classroom teaching strategies involving with modern technologies may enhance the student's interest in their lesson among the younger generation nowadays. Moreover, the model in flipped classroom strategies will maximize the uses of technologies when the process of the instructional based on flipped learning assignments or task given by the teacher to solve between the classroom and home. Felder and Strayer (2012), reported that the flipped classroom strategies sharing common features which involve with active and intentional transfer of information delivery outside of classroom with the purpose of making the face-to-face interaction among the students and teacher become more longer in the class. In addition, the students will become active learners rather than only accepting the information and at the same time the students will view the videos or teaching materials provided by the teacher again and again as needed. As a consequences of all these factors, the teachers have more time to conduct learning activities in the classroom as well as make the students collaborate more during the face-to-face 
instructional. Hamden et al. (2013) pointed out that by providing videos before the teaching and learning process in the classroom will maximize the time of face-to-face instructional process with interesting learning activities. As a result, the instructional process may stimulate the collaborative learning among the students and the teacher may get immediate feedback from the students.

Moore et al. (2014) reported that the special features about the flipped classroom learning strategies to enhance the interaction between teacher and students, students and students during the instructional process. The interactions between the teacher and students by one-on-one during learning in the classroom is one of the advantage by this teaching model. In addition, flipped classroom model is an example needed in $21^{\text {st }}$ century learning skills which encompasses with shaping the critical thinking, collaborative learning and selfdirection among the students (Framework for $21^{\text {st }}$ Century Learning, 2010).

The innovation in instructional is leading to adopting an active learning process in the classroom for the STEM discipline is the flipped classroom learning strategies. The flipped classroom learning strategies develop the student centered learning at out of the classroom, in this approach the learning process usually using the virtual learning technologies, and creates the problem solving activities among the students during in the classroom session (Christiansen, 2014; Seery, 2015). By giving the teaching resources like a videos, notes and task to the students earlier to be done as homework, the flipped classroom teaching model may build the active learning during discussion in the classroom.

Flipped classroom teaching strategies is about replacing an instructor with a collection of videos (Noschese, 2011). In this teaching strategies, the role of teacher might be affected due to online instructional videos. This critic points were referred to khan Academy website which stored more than 4000 video and viewed by 200 million of times. Khan (2011) expressed that goal of videos collection is to scale up the quality of education by providing world-class education to everybody. Moreover, the critics had been started about the need of teacher in education if there were many teaching resources were prepared in the website. According to Khan (2011), the use of videos collection was to practice flipped classroom strategies among the instructors through the online videos and focusing for learning activities, demonstrating simulations and laboratories with students.

\section{Previous Studies about Flipped Classroom}

Researches about flipped classroom teaching models were done with different background and contexts. As an example, a study conducted by Alzwekh (2014), about the effect of flipped classroom in teaching computer subject towards self-learning skill among school students in Saudi Arabia. In his study, he implemented the experimental study towards 26 female students. The group of experiment was exposed to flipped classroom teaching model on how to learn a topic in computer subject. The experimental students were learn the topic at home through the educational resources provided by the teacher. The finding in this study showed that an enhancement of self-learning skill among the treatment group. Moreover, this teaching model also contributed in learning abilities among the students and encouraging responsibility among them. The researcher suggested to apply flipped classroom teaching model into other subjects and provide the training program to teachers about flipped classroom teaching strategies. 
According to Almuaither and Alqahtani (2014), in their study about the effectiveness of flipped classroom teaching model in teaching for information security concept among 100 University's female students. In this research, the study showed that the increasing of achievement among the experimental group in studying information security concept. This study revealed that flipped classroom teaching model may enhance the achievement among the students of university.

The researchers suggested to encourage teachers and trainer to implement flipped classroom teaching model when conducting courses, seminars and workshops.

Almusawi (2014) conducted an experimental study about the effect of flipped classroom teaching model in teaching geography concept and to develop creative thinking skill among the primary students. The findings in this research stated that students who were learned through the flipped classroom teaching strategies may enhance their acquiring in geography concepts as well as developing the creative thinking skills.

According to Chipp's (2013), in his study about the impact of using flipped classroom in teaching mathematics among the university students. The subject in this study consisted 80 students. The group of the experimental study was exposed to the flipped classroom teaching model in learning mathematics while the control group was practiced with traditional teaching methods. The findings in this research revealed that the treatment's group in this study showed the better achievement for mathematics subject compared to the control group. The researcher suggested to the instructors to use modern technologies in flipped classroom teaching and learning process to develop positive effects in mental skill among the students during studying mathematics.

A study conducted by Herreid and Schiller (2013), about the use of flipped classroom teaching strategies among the members of national center in studying cases in teaching for science's subject revealed the flipped classroom teaching strategies provide sufficient time to learn in classroom with providing teaching devices and equipment. Moreover, flipped classroom teaching model makes the students to participate in learning activities and watching the lectures video that they have missed.

\section{Research Methodology}

The research design chosen in this study is an action research based on Kurt Lewin's Model (1948). In this model, there are four phases to complete a cycle of an action research. The phases are planning, action, observation and reflection. In this research, there were involved with pre-test, post-test and a survey to measure the level of interest among the students about the flipped classroom teaching strategies. The duration of this study takes about 9 weeks. 


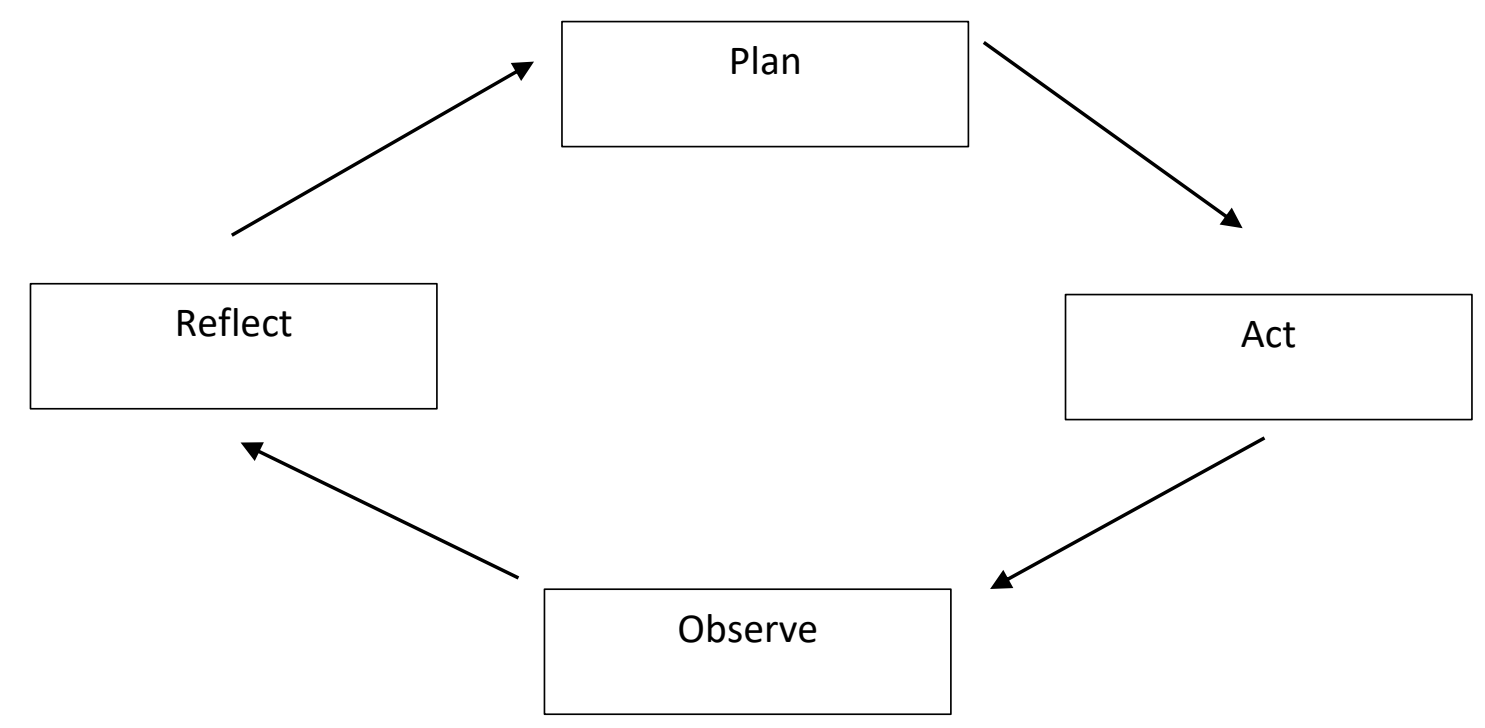

Diagram 1: Kurt Lewin's Model (1948)

In this study, the researcher used pre-test and post-test to measure the achievement of the students for acid and base topic. The achievement question comprises of ten objective questions, ten structured questions and two essays which are based on the SPM format. All questions are based on acid and base topic which is discussed in chapter seven in the form four chemistry textbook. The set of pre-test questions will be given to all of the students before conducting the action research or the treatment. The action research in this study is an example of intervention to students in order to enhance their academic achievement in acid and base topic. In this study, the teacher will provide the teaching resources like videos, notes, exercises in Google Classroom application. Then invited all of the students to view and study the teaching materials at home. During the class session, the students were asked to present and discussed the topic based on the exercises given in the Google Classroom application.

After finishing the treatment, the students will be given a set of post-test question papers. The purpose of giving the pre-test and post-test to the students to measure the level of achievement before and after the treatment had been done. A set of survey to measure the level of interest for flipped classroom teaching strategies among the students will be given at the end of the lesson. This survey is also a way to determine the effectiveness of the treatment in order to help the students in understanding and remembering the topic.

The location chosen in this study was one of the secondary school located in Hulu Langat, Selangor. The subjects in this study encompasses of form four chemistry students. There were 32 students which included 17 boys and 15 girls involve in this study. The age of the students were 16 years old while the study was being conducted.

The data collected from this study had been processed and analyzed using the descriptive and inferential statistics (paired sample t-Test) to determine the value of mean, standard of deviation, the differences of mean's score between pre-test and post-test in the sample group using SPSS's software version 23 and transformed into a histogram. The data also had been analyzed to compare the maximum marks, minimum marks and mean of the 
total marks among the students during the pre-test and post-test. The data from the survey will be analyzed based on the Likert scale 1-5.

The data from the survey will be analyzed in descriptive statistic. This analysis was used to determine the level of interest among the students towards the learning using the flipped classroom teaching strategies. The data will be interpreted into four level as shown in table below:

\begin{tabular}{cc} 
Men Score & Interpretation of Mean Score \\
$1.00-2.00$ & Low \\
$2.01-3.00$ & Medium low \\
$3.01-4.00$ & Medium high \\
$4.01-5.00$ & High \\
\hline
\end{tabular}

Table 1: Source: Nunnaly 1978

\section{Findings}

i) The achievement of students in acid and base topic before and after the teaching and learning using the flipped classroom strategy

\begin{tabular}{|c|c|c|c|}
\hline Number & Subject & Pre-test & Post-test \\
\hline 1 & student 1 & 50 & 66 \\
\hline 2 & student 2 & 45 & 60 \\
\hline 3 & student 3 & 54 & 64 \\
\hline 4 & student 4 & 52 & 68 \\
\hline 5 & student 5 & 54 & 62 \\
\hline 6 & student 6 & 48 & 64 \\
\hline 7 & student 7 & 56 & 66 \\
\hline 8 & student 8 & 58 & 68 \\
\hline 9 & student 9 & 50 & 64 \\
\hline 10 & student 10 & 56 & 70 \\
\hline 11 & student 11 & 60 & 76 \\
\hline 12 & student 12 & 54 & 68 \\
\hline 13 & student 13 & 50 & 66 \\
\hline 14 & student 14 & 54 & 68 \\
\hline 15 & student 15 & 58 & 70 \\
\hline 16 & student 16 & 48 & 62 \\
\hline 17 & student 17 & 50 & 70 \\
\hline 18 & student 18 & 52 & 66 \\
\hline 19 & student 19 & 46 & 60 \\
\hline 20 & student 20 & 48 & 66 \\
\hline 21 & student 21 & 50 & 72 \\
\hline 22 & student 22 & 52 & 62 \\
\hline 23 & student 23 & 46 & 60 \\
\hline 24 & student 24 & 54 & 66 \\
\hline 25 & student 25 & 56 & 70 \\
\hline 26 & student 26 & 46 & 64 \\
\hline 27 & student 27 & 50 & 70 \\
\hline 28 & student 28 & 58 & 72 \\
\hline 29 & student 29 & 52 & 64 \\
\hline
\end{tabular}




\begin{tabular}{|l|l|l|l|}
\hline 30 & student 30 & 46 & 66 \\
\hline 31 & student 31 & 48 & 70 \\
\hline 32 & student 32 & 54 & 70 \\
\hline Mean & 51.72 & 66.56 \\
Standard of Deviation & 4.11 & 3.88 \\
\hline
\end{tabular}

Table 2: Comparing between pre-test and post-test

The results showed that the mean value for the pre-test was 51.72 while for the post-test was 66.56. The standard of deviation for the pre-test was 4.11 while for the post-test was 3.88. Findings from the result showed that an increase of the mean value between pretest and post-test for achievement of students who were taught using the flipped classroom strategies for acid and base topic. This is shown when the value of mean for the pre-test (51.72) had increased to 66.56 in the post-test. Moreover, maximum marks in the pre-test (60) had increased to 76 in the post-test. The minimum marks in the pretest (45) also had increased in the post-test when the minimum marks were 60.

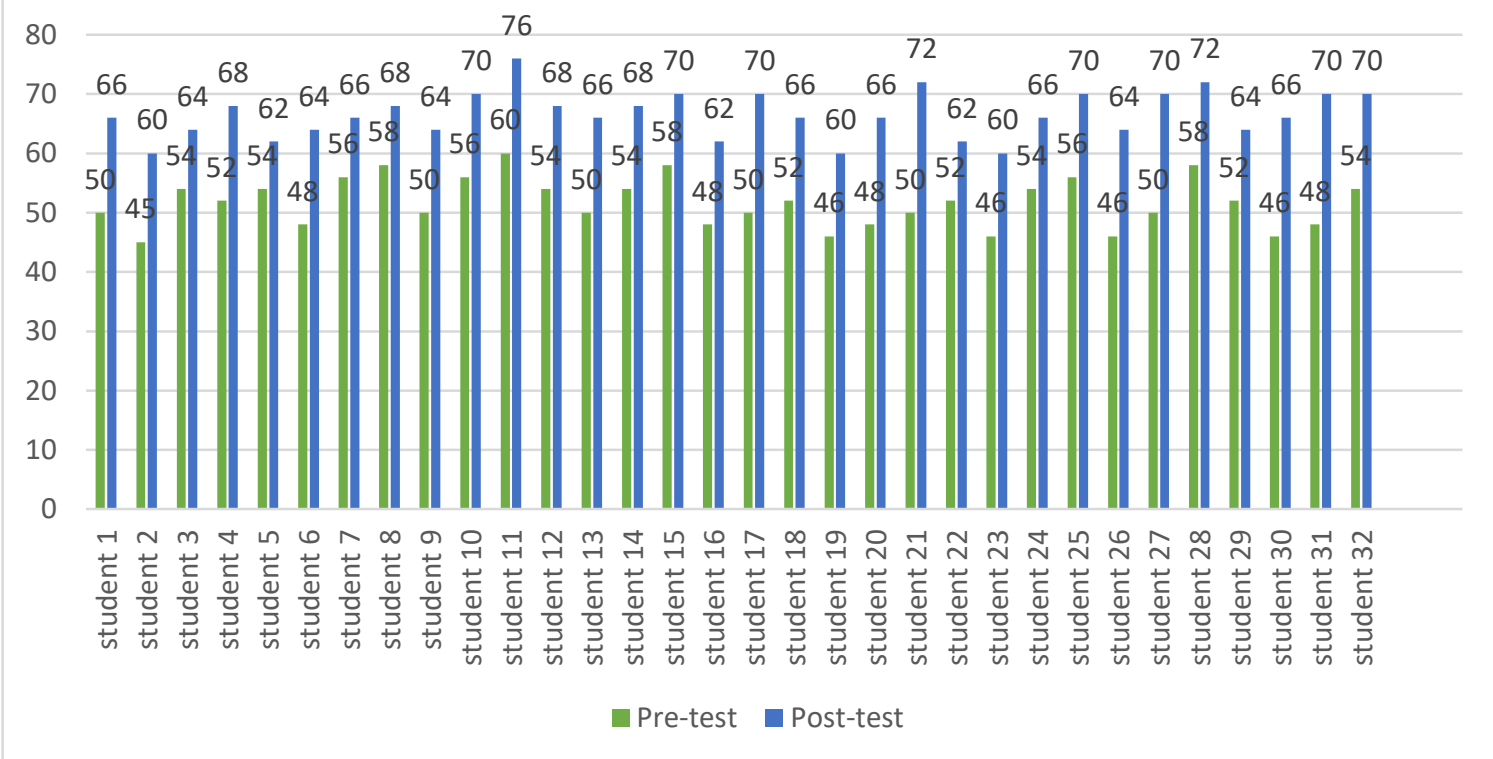

\section{Diagram 2: Graph of comparing pre-test and post-test}

The difference between maximum marks for the pre-test (60) and post-test (76) was 16 . The difference between minimum marks for the pre-test (45) and post-test (60) was 15 . The standard of deviation for the pre-test was 4.11 while the post -test was 3.88 . This showed that distribution of student's marks in the post-test were nearer than the distribution of student's marks in the pre-test.

\begin{tabular}{ccccccc}
\hline & Mean & $\mathbf{N}$ & $\begin{array}{c}\text { Standard } \\
\text { of } \\
\text { Deviation }\end{array}$ & $\mathbf{t}$ & df & Sig. \\
\hline Pre-test & 51.72 & 32 & 4.11 & -23.914 & 31 & 0.00 \\
Post-test & 66.56 & 32 & 3.88 & & & \\
\hline
\end{tabular}

Table 3: Result of paired samples t-Test 
Table 3 showed the result of paired samples t-Test analysis on pre-test and post-test for the students who learnt using the flipped classroom strategies for acid and base topic. Based on this table, the mean value for pre-test showed 51.71 ( $S D=4.11)$ while the post-test 66.56 $(S D=3.88)$. The difference of mean's score between post-test and pre-test was 14.85 . There was significant difference of mean's score $(t=-23.914, d f=31, p<0.05)$. The overall analysis from paired sample t-Test showed that students who learnt using the flipped classroom strategies had increased their academic achievement.

ii) The level of interest among the students when implementing flipped classroom strategy in teaching and learning for acid and base topic.

\begin{tabular}{|c|c|c|c|}
\hline Number & Item & Mean & $\begin{array}{l}\text { Standard of } \\
\text { Deviation }\end{array}$ \\
\hline 1 & $\begin{array}{l}\text { I feel more understand with the topic when } \\
\text { learn using flipped classroom teaching } \\
\text { strategies }\end{array}$ & 3.88 & 0.72 \\
\hline 2 & $\begin{array}{l}\text { I like to learn using flipped classroom teaching } \\
\text { strategies in every subject }\end{array}$ & 3.52 & 0.98 \\
\hline 3 & $\begin{array}{l}\text { I feel learning process through the flipped } \\
\text { classroom strategies easier than other } \\
\text { method. }\end{array}$ & 3.67 & 0.76 \\
\hline 4 & $\begin{array}{l}\text { I like new learning process with the } \\
\text { implementation of flipped classroom } \\
\text { strategies. }\end{array}$ & 3.76 & 0.88 \\
\hline 5 & $\begin{array}{l}\text { I feel learning process with flipped classroom } \\
\text { strategies may improve my knowledge. }\end{array}$ & 3.72 & 0.84 \\
\hline 6 & $\begin{array}{l}\text { I feel easier to remember the information in } \\
\text { my study when my teacher teach me through } \\
\text { the flipped classroom strategies. }\end{array}$ & 3.80 & 0.90 \\
\hline
\end{tabular}

Table 4: Value of mean and standard of deviation for student's interest for flipped classroom teaching strategies.

Based on Table 4, findings for student's interest for flipped classroom teaching strategies, item number 1 showed the highest value (Mean=3.88, SD=0.72) which students feel understand more with this topic when they learnt using flipped classroom teaching strategies while item number 2 showed the lowest value (Mean=3.52, SD $=0.98$ ) which were students like to learn using flipped classroom teaching strategies in every subject. The total of mean for level of interest among the students towards the flipped classroom strategies was at medium high (Mean=3.73). This finding, showed that students feel interested to learn using the flipped classroom teaching strategies for acid and base topic. Moreover, this teaching approached may improves students understanding for acid and base topic.

\section{Discussion and Recommendations}

This action research was aimed to examine if the flipped classroom teaching strategies may improve student's academic achievement as well as their interest in acid and base topic 
among form four chemistry students. Regarding student's academic achievement as measured in pre-test and post-test, there was an improvement in their marks from the pretest to the post-test. Every students showed their increasing of marks after finishing the flipped classroom teaching strategies for acid and base topic. Moreover, the implementation of flipped classroom strategies had shown the positive effect on all of the students in this study. This result is in agreement with previous research regarding the flipped classroom teaching model which found similar results in other area of subject including physic, chemistry, mathematics and engineering (Davies et al. 2013; Fautch 2015). Flipped classroom strategies is one of the treatment or intervention in helping students to easier in understanding lesson in acid and base topic. This treatment may enhance student's knowledge by providing videos, notes and exercise at home through the technology as well as discussing session in the classroom in order to build new knowledge. According to Bergmann, \& Sams (2014), in their study flipped classroom learning strategies may build a new internal knowledge among the students and give a positive impact in their academic performance as well as develop interaction among the students and teacher. This situation may result students engagement during the classroom session.

Flipped classroom teaching model could develop collaborative learning style when interaction among students occurred through the online and during classroom teaching session. This may generate interactive learning in the classroom as well as developing new knowledge and ideas based on their previous experienced and sharing of ideas. Students were actively giving their ideas and full of cooperating during the classroom learning session after they had studied the lesson at home through the google classroom application. Jeongsun and Dongsil (2009), had pointed out that in flipped classroom teaching model, students will actively cooperate with each other and develop collaborative learning through online learning, meaning the students acquire previous knowledge and generate new knowledge during the discussion and sharing the knowledge among the peers. It seems like flipped classroom teaching strategies may improve student's academic achievement through the cognitive activities in online learning such as collaborative activities, task performance, quiz and knowledge sharing as well as affected the cognitive changes among the students. However, this study was contradict to Strayer (2007), who had reported that students were not performing very well when they were teach using the flipped classroom teaching model. Similarly to the research conducted by Johnson and Renner (2012), who were reported that students who were learnt using computer application through the flipped classroom teaching model did not show an active learning process.

Regarding to the area of student's interest of implementing flipped classroom teaching strategy in teaching and learning for acid and base topic, the result and finding in this study indicate that students were interested to learn this topic through the flipped classroom teaching model. This showed when the value of mean was 3.73 which indicate that the frequency was at medium high level. The students felt easy to understand the lesson of acid and base through the flipped classroom teaching model due to the videos, notes and exercises provided by the teacher in the Google Classroom application. The animation in the videos could make the students easy to remember the chemistry processes involve in acid and base topic, especially during the neutralization process between acid and base to produce salt and water. Moreover, the notes and exercises in the Google Classroom application provided by the teacher could make the students improve their knowledge as well as relating with their previous knowledge and experience for study this topic. In flipped classroom 
teaching model, students were asked to do their preparations at home by viewing videos, notes and exercises provided by the teacher. This situation also make the students easy to study at home anytime without any pressure or supervision from the instructor. This finding similarly to the study conducted by Sowa and Thorsen (2015), which indicate students were preferred to study using the flipped classroom teaching model rather than traditional method due to flexible nature of this model. Moreover the students could view and prepare for their presentation earlier before coming to the class with teaching resources without any observation from the teacher or being embarrassed in front of class. As a consequences, flipped classroom teaching model is more convenient and enjoyable for students due to its easy to access.

The findings from this study recommended to every school should be provided with internet technologies which encompasses with modern computer laboratory, high internet coverage and personal computer for every teachers to help them in preparing teaching materials for the flipped classroom teaching strategies. Moreover, the findings also urge to provide training about the flipped classroom teaching model to all of pre-service teachers as well as adequate them with modern technologies for implementing their coming lesson at the school. Further researches about flipped classroom teaching model should be done with other variables, sample of study and subjects in order to investigate and discover new knowledge about this teaching strategies as well as improving the quality of pedagogy among the teachers.

\section{Conclusion}

This study was aimed to determine if flipped classroom teaching strategies could enhance the academic achievement and student's interest for acid and base topic among form four chemistry students. The findings from this action research showed that flipped classroom strategies was improved the academic achievement as well as the level of interest among the students. The teaching resources provided by the teacher which encompasses with videos, notes and exercise has helped the students to study and make preparations for their next classroom session at home without any stress and supervision from the teacher and other students. Moreover, the videos, notes and teaching materials provided by the teacher can be viewed by the students repeatedly anywhere and anytime so that the students can improve their knowledge on the topic. The discussion in the classroom session may develop the interactive learning among the students through the sharing of ideas and knowledge as well as collaborative learning style in the classroom. This active learning process may build the students interest to learn the subject taught by their teacher. The implementation of ICT in teaching and the learning process through the flipped classroom teaching model is one of the effort for teachers to scale up quality of learning across Malaysia using the ICT as stated in Malaysia Educational Blueprint (2013-2025) at the seven shift.

\section{Corresponding author}

Mohd Ariffuddin Abdul Aziz, Faculty of Educational Studies, University Putra Malaysia

Email: mohd.ariffuddin84@gmail.com 


\section{References}

Rahman, A. M. A. (2000). Manusia dan stress. Buletin Akademik. Universiti Pendidikan Sultan Idris. 2 (10-11).

Kassim, A. H. (2003). Kurikulum Sains Sekolah Malaysia. Modul Pengajaran. Universiti Teknologi Malaysia: Skudai, Johor.

Almuaither, R. \& Alqahtani, A. (2014). The effectiveness of the flipped classroom strategy in developing information security concepts among the female students at university level in the Princess Nora Bint Abdul Rahman University in Saudi Arabia. The International Educational Journal, 4 (8), 21-39.

Almusawi, A. Y. (2014). The impact of similarities strategy and flipped thinking in acquiring geographical concepts and developing creative thinking in middle school students. Unpublished Doctoral Dissertation, University of Baghdad, Baghdad, Iraq.

Alzwekh, N. (2014). The effect of applying flipped classroom concept on developing skills of self- learning in female students at the third level, computer course 2. Retrieved on September 8, 2017.from:http://almarefh.net/show_content_sub.php?CUV=428\&SubModel=216\&ID= 2295

Bergmann, J. \& Sams, A. (2012). Flip your classroom: Reach every student in every class every day. International Society for Technology in Education.

Bergmann, J., and Sams, A, (2014), Flipped Learning: Gateway to Student Engagement, Eugene, OR: International Society for Technology in Education.

Chipp, T. (2013). Falls classrooms flipping out thanks to new program. Retrieved on May 10, 2016 from: http://www.niagara-

gazette.com/communities/x1746084890/Falls-classrooms-flipping-out-thanks-to new-program/print

Christiansen, M. A. (2014), Inverted teaching: applying a new pedagogy to a university organic chemistry class, J. Chem. Educ., 91, 1845-1850.

Cohen J. (1988), Statistical power analysis for the behavioral sciences, 2nd edn, Hillsdale, NJ: Erlbaum Associates.

Davies, R. S., Dean, D. L., \& Ball, N. (2013) Flipping the classroom and instructional technology integration in a college-level information systems spreadsheet course. Educ Tech Res Dev 61(4):563-580

Fautch, J. M. (2015) The flipped classroom for teaching organic chemistry in small classes: is it effective? Chem Educ Res Pract 16(1):179-186

Felder, R. M. (2012) Engineering education - a tale of two paradigms. Paper presented at the SFGE, 2nd international conference on geotechnical engineering education, Galway

Framework for 21st Century Learning-The Partnership for 21st Century Skills. (2010). Retrieved 11 March 2016. http://www. p21.org/overview/skills-framework

Hamden, N., McKnight, P. E., McKnight. K., \& Arfstrom, K. (2013) A review of flipped learning. Flipped learning network. Pearson Education, Upper Saddle Rive

JeongSun, H., and Sik, K. D. (2009). "The Effects of Collaboration Supporting Types on Collaborative Knowledge Construction in CSCL Environment", The Journal of Korean Association for Information \& Media, vol. 15, no. 4, pp. 203-229.

Herreid, C., \& Schiller, N. A. (2013). Case studies and the flipped classroom. Journal of College Science Teaching, National ScienceTeachers Association, 62-66. 
Johnson L., \& Renner, J. (2012). Effect of the flipped classroom model on secondary computer applications course: student and teacher perceptions, questions and student achievement (Doctoral Dissertation, University of Louisville)

Kamarainen, A. M., Metcalf, S., Grotzer, T., Browne, A., Mazzuca, D., Tutwiler, M. S., \& Dede, C. (2013). ECoMOBILE: Integrating augmented reality and probeware with environmental education field trips. Computers \& Education, 68, 545-556.

Khan, S. (2011) About Khan Academy. Retrieved 26 February 2016. http://www.khanacademy.org/about

Ministry of Education (2012) Preliminary Report: Malaysia Education Blueprint 2013-2025, Ministry of Education, Kuala Lumpur, Malaysia.

Moore, A., Gillett, M., \& Steele, M., (2014) Fostering student engagement with the flip. Math Teach 107(6):22-27

Noschese, F., (2011) Khan Academy: my final remarks. Action- reaction: reflections on the dynamics of teaching. Retrieved 11 December 2015.

http://fnoschese.wordpress.com/2011/05/10/ khan-academy-my-final-remarks

Nunnally, N. C. (1978). Psychometric theory. New York: Mc Graw-Hill.

Seery, M. K., (2015), Flipped learning in higher education chemistry: emerging trends and potential directions, Chem. Educ. Res. Pract., 16, 758-768.

Sowa, L., \& Thorsen, D. (2015) An assessment of student learning, perceptions and social capital development in undergraduate, lower-division STEM courses employing a flipped classroom pedagogy. Paper presented at the 122nd ASEE Annual Conference \& Exposition

Strayer, J. F. (2007). The effects of the classroom flip on the learning environment: $A$ comparison of learn- ing activity in a traditional classroom and a flip classroom that used and intelligent tutoring system. (Doctoral dissertation, The Ohio State University Columbus, $\mathrm{OH}$ ).

Strayer, J. F. (2012) How learning in an inverted classroom influences cooperation, innovation and task orientation. Learn Environ Res 15(2):171-193

Teo, T. W., Tan, K. C. D., Yan, Y. K., Teo, Y. C. and Yeo, L. W., (2014), How flip teaching supports undergraduate chemistry laboratory learning, Chem. Educ. Res. Pract., 15, 550-567, DOI: 10.1039/C4RP00003J

Tully, D. (2014). The effects of a flipped learning model utilizing varied technology verses the traditional learning model in a high school biology classroom. MA Thesis, Montana State University, Boseman, Montana, Retrieved on 1st, September, 2017, from:

http://scholarworks.montana.edu/xmlui/bitstream/handle/1/3600/TullyD0814.pdf;sequ ence $=1$ 